also between ants and various plants known as Myrmecophytes.

The author takes occasion to combat Wasmann's view as to a special symphilic instinct in ants and termites. The latter observer adduces certain ascertained facts regarding Lomechusa strumosa, a beetle parasitic in the colonies of Formica sanguinea. The adult beetles are fed and licked by the ants, but the beetle larvæ devour the larvæ of their hosts; moreover, in some colonies the presence of the parasite leads to the development of pseudogynes-i.e. forms intermediate between workers and females, which are incapable of performing the functions of either caste. The infection of an ant colony by Lomechusa is therefore presumably detrimental to the hosts. This is admitted by Wasmann, who nevertheless contends that Formica sanguinea has acquired a special symphilic instinct, not under the influence of natural selection, but in connection with the use of a process analogous to artificial selection as practised by man. Mr. Wheeler holds, on the other hand, that the beetle is the aggressor, and that the fact that it is licked and tended by the ants is a mere incidental result of the nursing habits of the latter with regard to their own offspring.

F. A. D.

\section{PHYSICS IN SCHOOLS.1}

$\mathrm{N}$ opening the discussion described in the report before us, Prof C. H. Lees, president of the Physical Society, stated that the meeting was the outcome of the desire of the society to help those engaged in science teaching in public and secondary schools to carry out the extension of their work which will probably ensue in the course of the next few years. We may begin our notice of the report by congratulating those responsible for the idea of such a meeting and those to whom the credit of its skilful organisation belongs.

Sir Oliver Lodge opened with a characteristically direct remark:- "Mr. President, I very much agree that it is desirable that the average man should know more physics than he does at present. He could hardly know less." But the speaker did not pursue the delicate question as to the responsibility for this state of things, whether the average man or the teacher of physics is to blame. Nor need we inquire, since the one clear, unmistakable inference from the discussion as a whole was that teachers of physics are tackling with much thoughtful energy the problem of providing courses of physics which will suit those who will get in schools the only knowledge of physics they are ever likely to possess.

It is worth noting that Sir Oliver Lodge considers it best to begin with the biological sciences, for cultivating the faculty of observation. Why this should be so was not explained; nor was anything said as to how the power of observing gained in natural history studies was to be transferred to the field of physics. Here we touch on the

1 "The Teacbing of Physics in Schools." Report of a discussion at a meeting of the Physical Society, June 14,7973 . Pp. 43. (London: FleetwayF'ress, rgr 8.) Price $r s .2 d$. post free.

NO. 2564 , VOL. IO2] weak side of the discussion-there was too insecure a basis of psychological knowledge, too little recognition of the imperative primary need to find out how the boy's mind will work with spontaneity as well as under discipline.

There are several clear statements in this report on the distinction between physics for the boy who will specialise in science and "Physics for All," the contribution of Prof. R. A. Gregory being particularly clear and weighty. The need for inspiring courses was well emphasised by both the opening speakers; the Harrow syllabus submitted by Mr. C. L. Bryant was an able effort to meet this need.

Every schoolmaster feels one great difficulty in carrying out his ideals, viz. the narrow limits of time within which his work has to be carried out. Dr. T. J. Baker brought this point clearly before the society, and from this point of view criticised the recommendation of Sir J. J. Thomson's Committee to lower the school-leaving age from nineteen to eighteen. Probably the majority of schoolmasters, not excluding Dr. Baker himself, would be satisfied with an "Advanced Course" which ended with the end of the school year in which the age of eighteen was reached.

Mr. A. T. Simmons showed the further difficulties which arise when the school course ends at sixteen. Too often electricity and magnetism are left out, so far as the majority of the boys are concerred - a serious matter. We may point cut that this means not merely the loss of a study of fascinating interest to most boys, but the further result is that school-work and the life of the world remain divorced. Mr. Simmons did another service to the discussion by indicating things which could be left out with advantage; we suggest that one of the most necessary things to do at present is to scrap useless topics of the Nicholson hydrometer type.

If we take a longer view, it is obvious that for future progress the training of teachers of physics is of first-rate importance, and the remarks of Prof. T. P. Nunn will be read with interest. The two main theses were (I) the need for the teacher to have studied his subject critically, (2) the benefit which results from a sound apprenticeship to the teacher's art. We agree that "the way of wisdom with regard to training colleges is not to suppress or to ignore them, but to take serious pains to strengthen them for the better performance of their indispensable duties." In our opinion, the training of science teachers is one of the vitally important items of educational reconstruction, and this might well be impressed upon local education authorities during the coming year. The need for "refresher courses", for teachers who have been at work for several years, possibly in a remote school, has been recognised by the more progressive authorities; but such courses rarely include physics or chemistry. Mr. J. Nichol was only too well justified in directing attention to the financial difficulty of the science master who wishes to keep up to date (this applies especially to those whose school is 
far from a large town), and he was on equally sound ground when he urged that the teaching of physics should be revivified and kept in touch with everyday life, so as to defeat any attempt to standardise it and use it merely as a training in logical method ( $c f$. Euclid).

The meeting was saved from the peril of a tame unanimity by a difference of view as to approaching the subject synthetically, e.g. by building up a theory of heat from observations of the dissected phenomena of expansion, etc., or analytically, e.g. by starting with a steam-engine and inquiring how it works.

The difference was somewhat unreal-at least, the real issues were not clearly defined. Surely the problem is how to harness the "wonder" and "utility" motives, and this has to be solved for each method-unit according to the characteristics of each class and teacher and of the method-unit itself. Here it may be said that the existence of a method-unit was only once referred to, when Mr. F. B. Stead directed attention to the fault that the laboratory exercise that can be done in one lesson period tends to become the unit of teaching. We are of opinion that teachers should give more attention to sectioning their subject into natural method-units, using them for revision, for the pupil's more elaborate note-taking, and for essays. Perhaps the simplest example is "expansion by heat," which is so obvious that in practice regard to this topic as a method-unit is fairly well observed.

It is not possible within the limits of this article to refer to many useful practical suggestions which teachers may gain by reading this report. We have no doubt that many will be grateful to the Physical Society and to the speakers, not forgetting Dr. H. S. Allen, who organised the symposium.

G. F. D.

\section{NOTES.}

THE mineral resources of Spitsbergen have lately been receiving much attention. The signing of the armistice has allowed the two British companies which hold the principal mining estates in that country to make plans for resuming operations. A correspondence in the Times, initiated by Prof. F. Haverfield, of Oxford, has dealt with the value of the coal and ironores. Prof. Haverfield, who seems to prefer the German spelling of Spitsbergen with a "z," quotes Swedish geologists as denying the existence of high-grade iron-ores, and he characterises the attempts to utilise Spitsbergen commercially as a long series of failures from the time of the Dutch onwards. In these respects he has been misinformed. The Dutch and English whalers, and later the Russian and Norwegian trappers, did a rich trade in Spitsbergen produce. Mining ventures have not always been successful, but cases of failure have been due, not to lack of mineral ores, but to ignorance of Spitsbergen, to lack of political control in the country, and. in some instances, to mismanagement and amateur effort. During the war various Norwegian and Swedish companies, in several cases trespassers on British estates, mined large quantities of coal. This year about roo,ooo tons of coal were sent to Scandinavian ports. It is merely a question of effort to make Spitsbergen one of the chief coalproducing countries in Europe. The accessible coalNO. 2564 , VOL. IO2] fields are estimated to have a content of at least 4,000,000,000 tons of good steam-coal. The iron-ore deposits have yet to be examined by competent geologists and mining engineers, but the samples brought to this country promise well. Other mineral resources include gypsum in enormous quantities, asbestos, copper-ore, oil shale, and probably free oil. The mineral prospects of Spitsbergen are great, but, with the exception of coal and gypsum, need to be thoroughly prospected by qualified men before commercial development can proceed. Meanwhile, it is essential that Great Britain should keep a watchful eye on the fate of this terra nullius, in which British subjects have the principal claims.

WrTH the view of meeting the growing demand for technical literature, the council of the Chemical Society decided early in 1917 to increase the scope of the library of the society by a more liberal provision of suitable technical works and journals. It was also thought that by placing the existing library of 23,000 volumes and the proposed extension at the disposal of members of other societies and associations they might relieve themselves of the necessity of collecting and maintaining the literature relating to their special subjects, and assist in the formation of a representative library of chemical literature, such as would be difficult to obtain by individual effort. A conference of representatives of societies and associations connected with chemical science and industry was held to consider the means by which other societies, etc., might co-operate in this extension, and financial assistance was afterwards offered by the following societies, etc. :-Association of British Chemical Manufacturers, Biochemical Society, Faraday Society, Institute of Chemistry, Society of Dyers and Colourists, and Society of Public Analysts. Members of these contributing societies, etc., will be permitted to consult the library and borrow books from January x, 1919. The hours of opening the library will be as follows:Mondays, Wednesdays, and Thursdays, from to a.m. to 6 p.m.; Tuesdays and Fridays, from to a.m. to 9 p.m.; and Saturdays, from ro a.m. to 5 p.m.

IN the Fortnightly Review for December "Fabricius" refers to the manifesto in support of Germany's policy and action relating to the war signed by ninety-three university professors in that country in $19 \mathrm{r}_{4}$, and widely distributed. Among these professors were several occupying scientific chairs, and they must share the righteous condemnation which has been given by the intellectual world outside Germany to their misuse of authority on behalf of dishonourable dreams of conquest. As, however, most of the signatories of the manifesto were representatives of theology, law, literature, and like branches of knowledge, and not of science as it is usually understood, it is misleading to refer to them as a group of "scientists," as "Fabricius" does in the following extract from his article:- "Scientists are supposed to devote themselves to the promotion of science and of truth, for science is incompatible with untruth. However, the unceasing advocacy of a robber-policy and the exaltation of a robber-morality had so completely destroyed the instinct of responsibility and of truth amongst Germany's intellectual leaders that ninety-three of Germany's most eminent scientists, among them many prominent theologians and legists, disgraced themselves and German science for all time by issuing in I9I4 a manifesto to the world in which they mendaciously proclaimed that the other Powers had forced a war upon innocent and peaceful Germany; that upon France, England, and Russia rested the blood-guiltiness; that Germany 